\title{
THE DISSOLUTION AND THE REVOLUTION IN LONDON HOSPITAL FACILITIES
}

\author{
by
}

\begin{abstract}
BARRY G. GALE
[This] . . charitable foundation [St. Bartholomew's Hospital] so well devised by that famous and renowned King Henry the 8, hath since the times of the Gospel been much augmented: and is by the wise gouernours of the house as faithfully imployed to the comfort of many poore members of Christ, which by the charitie of that house, haue been healed of diuers diseases otherwise incurable. We reade that an angel stirred the poole of Bethesda and made it apt to cure all manner of diseases: but here not onely the angel of God goeth in and out among them, but Christ himselfe is present, assisting them in such charitable workes, and giuing a blessing thereunto.
\end{abstract}

Willet, Synopsis papismi, 1634, $1223^{1}$

AlthOUGH it has often been noted that the abolition of London's hospitals attendant upon Henry VIII's dissolution of the monasteries left a sizeable portion of the aged, indigent, and sick of that city without shelter, ${ }^{2}$ the positive benefits of this momentous act seem to have gone unnoticed. The theory that the Dissolution, by forcing London civic authorities to assume responsibility for their city's hospital care, might have set the stage for more progressive and more comprehensive hospital facilities apparently has never been suggested-let alone considered. The historian's emphasis heretofore has been on the unsympathetic king and plight of the ruthlessly dispossessed-never on the role the Dissolution might have played in initiating a great revolution in hospital care for Londoners; and hardly ever on the suggestion that such a revolution did indeed occur. What follows is an attempt to place the abolition of London's hospitals in a broader perspective: to note the positive, constructive results as well as the unfortunate; and to assess these results not only with regard to their immediate consequence, but in terms of their long-range significance as well.

England's hospitals in the two centuries before the Reformation underwent a gradual process of decay and dissolution-a process caused not from without by insensitive kings and their greedy advisers, but primarily from within by insensitive patrons and greedy hospital wardens. ${ }^{3}$

The abuses of the patrons were manifold. First, they often demanded of the recipient hospital immediate board and lodging for themselves and frequently for their favourites as well-an often excessive burden on the usually very limited

\footnotetext{
${ }^{2}$ Quoted in W.K. JoRdan, The Charities of London, 1480-1660, London, George Allen \& Unwin, 1960, p. 186.

${ }^{2} C f$., for example, Hermann LeVY, 'The economic history of sickness and medical benefit before the Puritan Revolution', Econ. Hist. Rev., 1943, 13, 47: 'The dissolution of the monasteries brought a depressing change. Of all the hospitals which the Middle Ages had founded, only a handful remained, with the result that throughout the country the sick, the poor and the aged were left almost unprovided for'.

See RotHa M. Clay, The Medieval Hospitals of England, London, Metheun, 1909, pp. 212-13, 222-23. I am using 'patron' here to refer both to the original patron and the original patron's descendants as well. It was the latter group that did the real damage.
} 


\section{B. G. Gale}

resources of the hospital. Second, they often rewarded aged or incapacitated members of their households with permanent maintenance at the hospital-still more taxing, one may suspect, because of the often lengthy nature of the obligation. Third, and perhaps most debilitating of all, the patrons showed a singular indifference and neglectfulness in their selection of the chief administrator of the hospital, the warden, who seems quite often to have become addicted to wholesale thievery. Examples of warden mismanagement and outright theft were numerous. In the fourteenth century at the hospital at Gloucester, for instance, pensions, jewels, corn, and even beds were reported having been sold. ${ }^{5}$ At St. Leonard's Hospital in Derby, a complaint was made in 1348 that the warden 'neglects the duties of the wardenship and has dissipated and consumed the goods and alienated the lands to the great decay of the hospital'. ${ }^{6}$ St. Bartholomew's Hospital in London was reported in 1380 to have been partially unroofed, pigs having access to it, the inmates lacking food and clothing, while the utmost depravity prevailed in the household. ${ }^{7}$ The prevailing corruption and its corrosive effects was clearly summed up in the preamble to the 1414 Statute for the reformation of hospitals:

Many hospitals ... be now for the most part decayed, and the goods and profits of the same, by divers persons, spiritual and temporal, withdrawn and spent to the use of others, whereby many men and women have died in great misery for default of aid, livelihood and succour. ${ }^{8}$

By 1480 the number of dissolved hospitals seems to have been considerable. Professor W. K. Jordan in a study of English hospitals in ten counties, has noted that of the 140 to 150 institutions founded in these areas prior to 1480 not more than seventyfour (only eight in London) were remaining by that year. And of the remaining, 'nearly half were either derelict or were so badly managed that almost the whole of their usually scanty income was being diverted or employed for essentially administrative (or bureaucratic) purposes'. ${ }^{9}$ Some hospitals were soon to be taken over by the colleges at Oxford and Cambridge; while still others were to be transformed into schools. ${ }^{10}$

By the eve of the Dissolution, the deteriorated state of England's hospitals apparently had not improved. Brinklow wrote (c 1536): 'I heare that the masters of your hospitals be so fat that the pore be kept leane and bare inough . . .;11 while Robert Copland, about the same year, in his poem The hye way to the Spyttell hous, lamented:

For I have sene at sondry hospytalles

That many haue lyen dead without the walles

And for lacke of socour haue dyed wretchedly

Vnto your foundacyon I thynke contrary.

Moche people resorte here and have lodgyng,

But yet I maruell greatly of one thyng

That in the nyght so many lodge without. ${ }^{12}$

Ibid., pp. 222-23.

Ibid., p. 223.

- Quoted in Courtney DaInton, The Story of England's Hospitals, London, Museum Press, 1961, p. 31 .

Clay, op. cit., p. 223.

Ibid., p. 212.

- JORDAN, Philanthropy in England, 1480-1660, New York, Russell Sage Foundation, 1959, pp. $258-59$.

10 DAInton, op. cit., p. 32.

11 Quoted in Clay, op. cit., p. 224. 


\section{The Dissolution and the Revolution in London Hospital Facilities}

At St. Thomas's Hospital, London, corruption was rife. On 4 July 1538, two years before the institution was surrendered to the king, one of the brethren, Robert Mory, was examined before the Justice of the Peace, Robert Acton, presumably after some complaint had been made concerning the loss of hospital property. Mory testified: 'Before the robbery of church plate the Master of the Hospital [Richard Mabott] sold two silver parcel gilt basins, a silver holy water stoup and sprinkler, a pair of silver candlesticks, parcel gilt, a silver parcel gilt censer, a pair of silver parcel gilt cruets, saying, "the world is naught, let us take while we may." Mabott then gave Mory $£ 5$ as the latter's portion of the loot. ${ }^{18}$

In London the Dissolution put an end to the medieval hospital system, without, however, providing for any new system to take its place. Numerous aged and sick people were, as a result, deprived of shelter. Many were probably taken in by friends and relatives, but still others were left to languish in the streets. London civic authorities were forced either to establish a new system of hospital care or put up with what was swiftly becoming a public scandal.

In 1538 they addressed a formal petition to King Henry VIII, which, after noting the 'myserable people lyeng in the streete, offendyng every clene person passyng by the way wt theyre fylthye and nastye savors ....,' requested that to alleviate such conditions the hospitals of St. Mary, St. Bartholomew, and St. Thomas, and the New Abbey at Tower Hill, with all the rents and revenues of the same, be transferred to the 'order rule dysposicon and governance' of the City of London. ${ }^{14}$ Had this been all the petition had requested, the citizens perhaps would have had greater chance of success. But the petition went on. The City further requested, 'for the avoydyng of the great infeccon and other inconvenyences that be lyke to happen to yor cytezyns . . . by reason of the great multytude of people . . . whiche dayly resorte to the paryshe churches . .. 'since the monastery churches had been closed, the governance of the churches, lands, and tenements within the precincts of the four chief orders of friars ${ }^{15}$ - property, the citizens must have realized, of enormous value. ${ }^{16}$

The result, perhaps not unexpectedly, was that the King did not even deign to reply. Various entries in the minutes of the Court of Aldermen indicate that the City continued efforts to secure a favorable answer, but apparently without result. By August 1540, London civic authorities were reduced to offering 1,000 marks for the houses and churches of the friars alone, 'if they can be gotten no better cheap'. Henry called the citizens 'pinchpence', though by 1541 he apparently had promised the City the churches of the Black, Grey, and White friars, for contributions had already been collected from the Companies for their maintenance. But the scheme apparently came to nought. ${ }^{17}$

The outbreak of the wars with Scotland and France, however, had shifted the

13 Quoted in E. M. McInnes, St. Thomas's Hospital, Springfield, Ill., Charles C. Thomas, p. 21. 14 See 'Petition of the Mayor, Aldermen, and Commonalty of the City of London to King Henry the Eighth, in the 30th year of his reign, 1538', in London Court of Common Council, Memoranda, References, and Documents relating to the Royal Hospitals, London, Benjamin Pardon, 1863, Appendix I, pp. 1-4.

${ }^{16}$ Ibid.

16 See Euza JefFries Davis, 'The transformation of London', Tudor Studies, ed. R. W. SetonWatson, London, Longmans, Green \& Co., 1924, p. 301.

${ }_{17}$ Ibid., pp. 301-302. 


\section{B. G. Gale}

advantage in bargaining from the King to the City, 'which had helped him with men, with money, and with its credit, pledged for the repayment of large sums advanced by continental financiers'. ${ }^{18}$ Just before Henry sailed for Boulogne in 1544 he refounded St. Bartholomew's Hospital along semi-religious lines. This organization the City found unsatisfactory. In December 1545, the Common Council appointed a committee to provide for the relief of the poor and the sick. ${ }^{19}$ Its negotiations with Henry ended, with the latter on his death-bed, in the comprehensive agreement (Letters-Patent dated 13 January 1547) ${ }^{20}$ whereby St. Bartholomew and Bethlehem hospitals, along with most of their property, were transferred to the City. The churches, lands, and buildings within the precincts of the Grey friars were also made over, as were the rectorial income and churches of two adjacent parishes. The citizens, in return, were required to contribute 500 marks annually towards the maintenance of the hospitals, make proper provisions for religious services in the areas concerned, and devote the remaining revenues to the relief of the poor.

Meanwhile the City had been preparing the way for the creation of three more London hospitals. Late in Henry's reign, the premises of the suppressed St. Thomas's Hospital had been purchased from the Crown, and in 1552 the refurbished institution was reopened for patients. ${ }^{21}$ Later in the same year, the newly-created Christ's Hospital, built in part upon the former site of the Grey Friars, was opened for the reception of 380 orphan children. Christ's was the product, in large measure, of Bishop Ridley's moving supplications to the young King Edward VI, though the efforts of the then Lord Mayor of London, Sir Richard Dobbes, must also be accounted of importance. ${ }^{22}$ The fifth and last of the new London hospitals took shape in 1553 when the dying Edward promised the decaying Royal palace, Bridewell, to the City for hospital use. It was not until 1556, however, that Mary reluctantly relinquished it. ${ }^{23}$ Bridewell was to serve as a quasi-punitive institution for the rehabilitation of London's rising vagabond population. ${ }^{24}$

With the Dissolution and the consequent assumption of responsibility for London's hospitals by City officials, a wholly new and profoundly more comprehensive and progressive hospital system began to take shape. Four prominent features may be noted.

First, the new system was characterized by what we might term the 'bourgoisization' of the hospital administrations. Take, for example, St. Thomas's Hospital. We have already noted its corruption-rife condition on the eve of the Dissolution. ${ }^{25}$ Following its refoundation, the governors, who appear to have been men of considerable business experience and acumen, set about establishing St. Thomas's on a sound financial basis. Some helped the treasurer of the hospital to buy supplies at the lowest possible price. Some would ride to the great annual fairs, such as the one at Stourbridge, to make money-saving bulk purchases of provisions. Still others visited estates of

18 Ibid., p. 302.

${ }^{20}$ See London Court of Common Council, Memoranda, References, and Documents, Appendix V, pp. $20-45$.

${ }_{21}$ DAVIS, op. cit., p. 302.

22 MCINNES, op. cit., pp. 22-23.

23 DAVIS, op. cit., p. 303.

24 JORDAN, Charities of London, p. 194.

${ }^{25}$ See p. 93. 


\section{The Dissolution and the Revolution in London Hospital Facilities}

the hospital to hold manorial courts and to inspect the standard of husbandry on the hospital's farms. ${ }^{26}$ But the governors offered more than just free time and advicethey were willing to donate their money as well. For example, in 1577 ten dozen quilts were needed for the patients. One governor offered to supply twenty while six others promised to supply ten each; later in the same year five more governors also promised ten each. ${ }^{27}$

Second, the new hospital system was characterized by a quite considerable expansion in the scope, and improvement in the quality, of medical facilities. What appears to have been the rather haphazard, unsystematic organization of the old hospital system was replaced by the diversified and comprehensive organization of the new. For example, each hospital in the new system was designed to meet the particular needs of the various patient populations of the City. Bethlehem was to care for the insane; St. Bartholomew's for the general sick; St. Thomas's for the permanently infirm (mostly geriatric); the orphan poor were to be fed, clothed, and educated at Christ's; and at Bridewell, vagabonds and other undeserving were to be made to work. ${ }^{28}$

Perhaps more importantly, following the Dissolution professionally trained medical personnel began to appear on the staffs of the hospitals. For example, at the time of St. Thomas's dissolution (1540), there is no indication of trained medical men on its staff. When the hospital reopened its doors in 1552, six surgeons were part of the staff; and in 1556, a physician was added. ${ }^{29}$ At St. Bartholomew's the story is much the same. Before its refoundation, there is no indication of trained medical men on its staff. By 1549 three surgeons had been appointed; and in 1568 a physician was added. Some years later four surgeons and four physicians were part of the hospital's medical team. ${ }^{30}$

The hospitals seem also, after their secularization, to have become sought-after training grounds for prospective surgeons. We are told that at St. Bartholomew's, for instance, the training conditions had become so good that the staff there were chosen from the top prospective apprentices. ${ }^{31}$

Third, and this is closely related to the improved medical facilities, the new hospital system was characterized by the beginnings of its integrations into the larger English medical establishment. After the Dissolution some of the greatest English men of medicine became associated with London's hospitals. Thomas Vicary, for example, Master of the newly-formed Barber-Surgeons' Company, Sergeant-surgeon to Henry and Edward (and later to Mary and Elizabeth), and perhaps the leading surgeon of the time, was appointed on 29 September 1548 a governor of St. Bartholomew's Hospital, and was reappointed each year until June 1552, when he was made 'one of the assistants of this house for the terme of his life.' Vicary lived in the hospital, where his house was kept in repair and from which he received an annual grant of livery. On 2 October 1554, Vicary was appointed head of the hospital in the absence of the governors. ${ }^{82}$

20 MCINNES, op. cit., p. 25.

37 Ibid.

${ }^{28}$ Davis, op. cit., pp. 302-303.

20 DAINTON, op. cit., pp. 52-53.

80 Ibid., p. 38.

1 Ibid., pp. 42-43.

s2 ThOMAs VICARY, Dictionary of National Biography, vol. 20, p. 300. 


\section{B. G. Gale}

William Clowes, Surgeon to Queen Elizabeth, and a man of considerable medical reputation, also became associated with St. Bartholomew's, being appointed to the staff in 1575. '[At the hospital] . . . he produced some of the best surgical writings of the day', one scholar has noted, 'almost unique in that they were more than the usual compilations from authorities ..... .33

Fourth, and lastly, there was a quite substantial increase in both the amount and number of benefactions given in support of the new hospitals. Thanks to the valuable researches of Professor W. K. Jordan, our figures here are fairly complete. ${ }^{34}$ Take Bethlehem Hospital, for example. In the decade 1491-1500, £1 7s. was given towards its support; in the two following decades, $£ 117 \mathrm{~s}$. and $£ 165 \mathrm{~s}$. were donated respectively. After the hospital's secularization, a slow but steady accumulation of endowments was made, principally in the form of small bequests from a large number of London burghers. By 1632, when a report of the condition of the hospital was made to the Privy Council, capital gifts in the total of $£ 10704 s$. had been made. ${ }^{35}$

The increase was more impressive at St. Bartholomew's. There prior to the Dissolution seven small benefactions totalling $f 10$ were noted in the period 1480-1540; in the brief interval 1547-1550 there was a total of fifteen benefactions amounting to $£ 289$ 10s. Thus in a period twenty times as short almost thirty times as much money had been given. In the next decade scores of gifts were given, the total reaching $£ 189712 s^{36}$

At Christ's Hospital the record of benefactions was most impressive. London tradesmen, shopkeepers, and burghers literally poured money into this institution. By 1610 the gifts and bequests made for its endowment had reached the considerable sum of $£ 45,9996 \mathrm{~s}$.; by $1630, £ 58,31715 \mathrm{~s} .{ }^{37}$

After the establishment of the new secular hospital complex, benefactions to the hospitals seem to have become part of the wealthy Londoner's way of life. 'From 1560 onwards', Professor Jordan has noted, 'the tradition was well established that every London merchant of substance left at least something to one or more of the London hospitals. ${ }^{38}$

Thus, viewed in this broader perspective, the Dissolution may be seen to have had, overall, a positive, constructive affect upon the state of London's hospitals, instead of the bleakly negative one that is so often pictured.

\section{ACKNOWLEDGEMENTS}

I wish to thank Professors Allen G. Debus and Charles M. Gray, both of the University of Chicago, for their generous assistance in the preparation of this paper.

"3 GoldwIN SMrth, 'The practice of medicine in Tudor England', Scientific Monthly, 1940, 50, 66. For more on the state of medicine in Tudor England see: SIR ARTHUR S. MACNALTY, The Renaissance and Its Influence on English Medicine, Surgery and Public Health, London, Christopher Johnson, 1946; W. S. C. Copeman, Doctors and Diseases in Tudor Times, London, Dawsons of Pall Mall, 1960; and 'The Royal Hospitals before 1700', in The Evolution of Hospitals in Britain, ed. F. N. L. Poynter, London, Pitman Medical Publishing Company, 1964.

\& JORDAN, Charities of London pp. 186-96. It should be noted that Jordan's figures are not adjusted for the extensive inflation that occurred in mid-sixteenth century England. Even when they are, however, the increases in benefactions noted are not too greatly diminished and the increase in the number of contributions is not affected at all. For the approximate percentage of price rise per decade see Y. S. BRENNER, 'The inflation of prices in early sixteenth century England', Econ. Hist. Rev. 1961-62, 14, 225-39.

8s JoRDAN, Charities of London, p. 189.

s? Ibid., pp. 191-92.

36 Ibid., p. 188.

so JORDAN, Philanthropy in England, p. 274. 